Censorship and Cultural Sensibility 
This page intentionally left blank 


\section{Censorship and \\ Cultural Sensibility}

The Regulation of Language in

Tudor-Stuart England

Debora Shuger

$\overline{\mathrm{PENN}}$

University of Pennsylvania Press

Philadelphia 
Copyright $(2006$ University of Pennsylvania Press

All rights reserved

Printed in the United States of America on acid-free paper

$\begin{array}{llllllllll}10 & 9 & 8 & 7 & 6 & 5 & 4 & 3 & 2 & 1\end{array}$

Published by

University of Pennsylvania Press

Philadelphia, Pennsylvania 19104-4112

Excerpts from the essay "Civility and Censorship in Early Modern England" by Debora Shuger, originally published in Censorship and Silencing Practices of Cultural Regulation, ed. Robert $C$. Post, reprinted, with changes, by permission of the publisher. (C) 1998 by the Getty Research Institute (formerly the Getty Research Institute for the History of Art and the Humanities, Los Angeles, CA).

Library of Congress Cataloging-in-Publication Data

Shuger, Debora K., 1953-

Censorship and cultural sensibility: the regulation of language in Tudor-Stuart England/ Debora Shuger.

p. $\mathrm{cm}$.

Includes bibliographical references and index.

ISBN-13: $978-0-8122-3917-1$

ISBN-10:0-8122-3917-2 (cloth: alk. paper)

1. Freedom of the press-England-History-16th century. 2. Freedom of the pressEngland-History-17th century. 3. Politeness (Linguistics)—England-History16 th century. 4. Politeness (Linguistics)-England-History-17th century. I. Title. KD4112.S55 2005

$342.4208^{\prime} 53-d c 22$ 
For Russ 
This page intentionally left blank 